\title{
Paradox of Success of Punjab Agriculture in Global Village: A Study on Challenges and Suggestions
}

\author{
Mnisha Shoor \\ Assistant Professor of Economics, Govind National College, Narangwal, Ludhiana, Punjab, India
}

\begin{abstract}
Punjab is among the richest states in India which throbs with vibrant people moving on the path of prosperity and is mainly called Bread Basket of nation. With advent of green revolution state has witnessed tremendous production of food grains in mainly wheat and rice. But the trend of globalization has decelerated the agricultural production growth rate by posing number of challenges in the form of WTO and OCED rules regarding Agreement on Agriculture, reduction in subsidies, high import duties, TRIPs related agreement. The Punjab's agriculture sector has reached a point where immediate action is required to regain its leadership role. The paper examines the prosperity of state and challenges to Punjab's agriculture in globalized world. The thrust of the paper is to suggest agricultural reforms for future course of action at domestic and international level.
\end{abstract}

Keywords: Green revolution, Patent Rights, HYV holdings, Export Potential

\section{Introduction}

Punjab - the food basket of India is predominantly an agricultural state where every aspect is influenced by farming, livestock, dairy and fisheries. Introduction of high yielding varieties of wheat and rice in late 1960s has contributed to the path of progress for the state. Development of irrigation, improved infrastructure, strong institutional reforms and high use of fertilizers contributed to success of green revolution. Punjab produces 20 percent of India's wheat and 9 percent of rice indicating its rising prosperity. Punjab contributed 43.4 percent of wheat and 29.3 percent of rice to central pool during 2013-14.

Punjab produces more than the requirements of the state. In 1947 , after the partition of the country there was shortage of 3500 tonnes of foodgrains. But with advent of green revolution in 1960's, the production of food grains have shown remarkable results. The state now a days not only meet the requirements of its own people but also exports large quantities to other states as well as in international market. During the period of 1966 and 2014, the production of foodgrains have increased eight times in Punjab whereas it is just 2.8 times for entire nation. The spine-shivering features of Punjab's agriculture are as follows:

1. Punjab produces 20 percent of the India's wheat, 9 percent of India's rice, 2 percent of world's cotton, 2 percent of world's wheat and 1 percent of world's rice (Economic Survey of Punjab 2012-13). The contribution of agriculture sector to net domestic product of Punjab is 6 percent

2. Green Revolution has significantly contributed to making Punjab one of the richest states. In 2013-14, agriculture sector contributed 20.83 percent to the GSDP and as per census 2011, 36 percent of the total workers depends on it. Thousands of people get employment in agroindustries such as sugar, cotton, food processing industry etc. (Johl, 2002). Acute shortage of labour is felt during sowing and harvesting in Punjab. So, large number of labourers migrate from UP and Bihar to Punjab.

3. The state is amongst the highest ranking states in country in terms of productivity of wheat and rice. The state has highest yield of rice (3741 kg per hectare) and second highest yield of wheat (4898 $\mathrm{kg}$ per hectare) after Haryana. The agricultural sector is instrumental in ensuring national food security by consistently contributing a significant percentage of wheat and rice to central pool. Punjab has contributed 43.4 percent of wheat and 29.3 percent of rice to central pool during year 2013-14 (Ministry of Agriculture, 2014).

4. Punjab agriculture is known for the use of high yielding varieties. During 2012-13, 100 percent area of wheat, rice and bajra and 96 percent area of maize were under the use of high yielding varieties. There is a shift towards exploration of agro business opportunities into nontapped areas which assure remunerative prices from certain crops like maize, sugarcane, farm forestry and cotton.

5. Chemical fertilizers are being used at rate of $236 \mathrm{~kg}$ per hectare in Punjab as against $144 \mathrm{~kg}$ per hectare in India. In 2009-10, insecticides weighing 5810 tonnes were used in Punjab to save crops from diseases and pests. The use of harvesters, tractors and other machines have increased at rapid pace favouring mechanization of agriculture in Punjab. In Punjab, 85 percent of net sown area is under multiple cropping.

6. Punjab produces export significant volume of agro products out of their huge agro production. Analysis of Director General of Commercial Intelligence \& Statistics, 2014 indicates that percentage contribution of agro products exports in Punjab's total production is increasing which is a healthy sign for an economy where more than 50 percent of population is dependent on agriculture. Punjab agro exports counted for Rs. 3698 crores in 2009-10 that has increased to Rs. 11098 crores in 2013-14.

7. Farmers in Punjab are also shifting towards changing consumption patterns of households towards high value horticulture product like vegetables and fruits, dairy products and animal products. The government is also implementing a scheme to encourage crop diversification through development of horticulture. Five citrus estates have been set up and new varieties of citrus fruits are being supplied to the farmers. The areas under fruit cultivation have increased from 0.68 lakh hectares in 1990-91 to 0.72 lakh hectares in 2012-13. 


\section{International Journal of Science and Research (IJSR) \\ ISSN (Online): 2319-7064 \\ Index Copernicus Value (2013): 6.14 | Impact Factor (2015): 6.391}

8. As far as livestock is concerned, its contribution has increased to 7.10 percent to the GSDP at constant (200405) prices in 2012-13. Punjab has shown growing trends in production of eggs and average annual growth rate of eggs production is higher than national average.

9. Farming is done in Punjab not only for the sake of subsistence but for earning profits by selling produce in the market. Therefore the concept of subsistence farming has been replaced by the commercial farming. In order to store agricultural produce Food Corporation of India, Markfed, Punsup, central and state warehousing corporations have set up their own warehouses that stored 31 lakh tonnes in 1976 but now increased to 252 lakh tonnes in 2010-11.

10. The number of small holdings and their percentage in total holdings is decreasing though the pace is quite slow. Except Nagaland (4.83 hectares) and Rajasthan (3.96 hectares) average size of holdings in Punjab was highest in India in 1995-96 although this share decreased to 35.4 percent in this year from 56.53 percent in 1971 (for marginal and small holdings). The share of semi-medium (from 2 to $4 \mathrm{ha}$ ) and medium (from 4 to 10 hectares) holdings that constituted 26.19 percent of total holdings in 1971 increased by 7.3 percent in 1995-96 compared to marginal and small holdings. The credit for this goes to green revolution.

\section{Performance of Agriculture in Punjab}

The contribution of Punjab in agricultural sector is immense. It has always remained central to economic development of the nation. The growth of agricultural sector in state following green revolution significantly contributed to making it one of the richest states in the country.

Table1 related to contribution of Punjab in economic development of nation clearly reveals that earlier in 2010-11 the contribution of wheat to the central pool was 45.4 percent which decreased to 33.6 percent in 2012-13 but finally paced up again to 43.4 percent in 2013-14 indicating positive trend.

Similarly contribution of rice to central pool was 25.3 percent in 2010-11 but now increased to 29.3 percent in 2013-14 although it too fluctuated in between years.

Table 1: Significance of Punjab Agricultural Sector to Indian Economy

\begin{tabular}{|c|c|c|c|c|c|}
\hline \multicolumn{7}{|c|}{ Contribution to central pool } \\
\hline Wheat & (lakh tones) & 102.1 & 109.6 & 128.3 & 108.97 \\
\hline Rice & (lakh tones) & 86.3 & 77.3 & 85.6 & 81.06 \\
\hline Wheat & $\%$ & 45.4 & 38.7 & 33.6 & 43.4 \\
\hline Rice & $\%$ & 25.3 & 22.1 & 25.1 & 29.3 \\
\hline
\end{tabular}

\begin{tabular}{|c|c|c|c|c|c|}
\hline Item & Unit & $2010-12$ & $2011-12$ & $2012-13$ & $2013-14$ \\
\hline $\begin{array}{l}\text { Foodgrain } \\
\text { production }\end{array}$ & $\begin{array}{c}(000 \\
\text { tonnes }\end{array}$ & 27846 & 29085 & 28502 & 27801 \\
\hline
\end{tabular}

Source: Punjab Economic Survey 2013-14.

In Punjab 82.6 percent of total area is under cultivation where as it is just 43 percent for entire nation. Punjab is the only state having largest net area sown more than once. The highest area under agriculture in Punjab is in Ferozepur district which has 87 percent of total area under cultivation.
Although Sangrur district has 97 percent of area sown more than once in year but still records maximum suicidal deaths among farmers .

Kapurthala the smallest district in Punjab has 87 percent of its total area under cultivation. Hoshiarpur district occupies the last position in terms of area under cultivation sown more than once in a year.

Table 2: Changes in areas under cultivation in different years in Punjab

\begin{tabular}{|c|c|c|c|c|}
\hline Year & $\begin{array}{c}\text { Total } \\
\text { Area }\end{array}$ & $\begin{array}{c}\text { Net sown } \\
\text { area }\end{array}$ & $\begin{array}{c}\text { Percent } \\
\text { sown area }\end{array}$ & $\begin{array}{c}\text { Total } \\
\text { cropped area }\end{array}$ \\
\hline $1970-71$ & 5031 & 4053 & 81 & 5678 \\
$1989-90$ & 5036 & 4271 & 84 & 7553 \\
$1999-00$ & 5030 & 4237 & 84 & 7847 \\
$2002-03$ & 5036 & 4224 & 84 & 7826 \\
$2003-04$ & 5036 & 4201 & 83 & 7905 \\
$2006-07$ & 5036 & 4184 & 83 & 7861 \\
$2010-11$ & 5036 & 4158 & 82.6 & 7882 \\
\hline
\end{tabular}

Source: Statistical Abstract of Punjab.

In 2013-14, the sector contributed 20.83 percent to the GSDP. The state is amongst the highest ranking states in country in terms of productivity of wheat and rice. It has highest yield of rice and second largest yield of wheat. It is consistently contributing significant percentage of wheat and rice to the central pool.

Productivity of wheat is higher in Punjab as compared to average productivity of China, Pakistan and USA but lower than that of France and UK. The productivity per hectare of rice and maize in Punjab is less than that of China, Japan, USA etc. Moreover, productivity of various crops in different districts has not been uniform. The productivity or rice in Gurdaspur, Kapurthala, Hoshiarpur and Patiala is less than overall productivity of Punjab whereas it is highest in Fatehgarh Sahib.

Table 3: Average productivity of crops in different countries

\begin{tabular}{|c|c|c|c|}
\hline Countries & Rice & Wheat & Maize \\
\hline China & 6350 & 3832 & 4933 \\
France & 5714 & 6632 & 8593 \\
Italy & 5989 & 2822 & 8942 \\
Japan & 6659 & 3639 & 2400 \\
USA & 6690 & 7076 & 7974 \\
India & 2102 & 2619 & 1938 \\
Punjab & 3868 & 4210 & 3123 \\
\hline
\end{tabular}

Source: Ministry of Agriculture, Government of India

\section{Declining Trends in Agriculture after 1990s}

All these indicators prove that agriculture in Punjab has improved with advent of green revolution. But the agricultural growth rate decelerated after globalization. In 1990 the overall growth rate in agricultural net domestic product for Punjab was 2.3 percent while for the rest of India it registered 3.3 percent.

In 1960s, 1970s and 1980s the shortage of foodgrains in other parts of India was major source of absorption of surplus produced in Punjab. However, in 1990s as deficit of other states reduced (especially northern and northeast states) due to increased agricultural productivity and the market for 


\section{International Journal of Science and Research (IJSR) \\ ISSN (Online): 2319-7064}

Index Copernicus Value (2013): 6.14 | Impact Factor (2015): 6.391

excess supply of foodgrains from Punjab declined. The share of primary sector has come down from 32.67 percent in 2004-05 to 20.84 percent in 2013-14 while that of secondary increased from 24.74 percent in $2004-05$ to 28.30 percent in 2013-14.

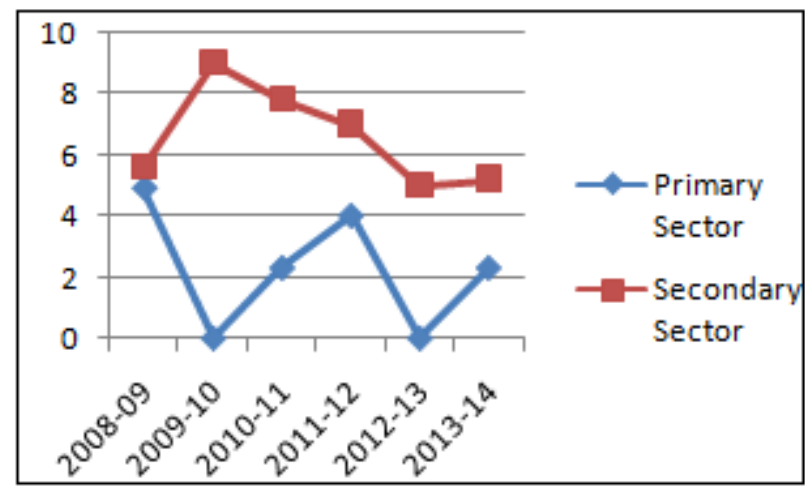

Figure 1: Sub sectoral growth trends (\%) in Punjab economy at constant (2004-05) prices

\section{Challenges to Agricultural in Punjab due to Globalization}

Under the present trend of globalization, privatization and setting of world trade regime, there has been subsequent reduction in production subsidies paid by developed countries to their farmers and rolling back certain non-tariff barriers. Export subsidies, market access and domestic support are the main basis of Agreement on Agriculture for India. Major role is being played by Trade Related Intellectual Property Rights (TRIPS) in protecting intellectual property rights. Growing scale in food business in terms of processing, distribution and retailing has been prevalent in developing nations.

\section{- Reduction in subsidies}

NTO agreement on agriculture stipulated that developed countries would reduce their subsidies by 20 percent in six years and developing nations by 13 percent in 10 years. However, India tried to manipulate this by providing green box and blue box subsidies as Indian agriculture which is a gamble of monsoon cannot survive at its own.

Green Box Subsidies include amounts spent on government services like research, disease control and food security. It also induced payments made directly to farmers like certain forms of direct income support assistance to help farmers restructure agriculture.

Blue Box Subsidies are certain direct payments where farmers are to limit production, certain government assistance programmes to encourage agriculture and other support on small scale when compared with total value of products supported 15 percent or less in case of developed countries and 10 percent or less for developing nations.

\section{- Lower prices of agricultural products in foreign markets}

Most of the times the agricultural prices of Indian products were much lower than international prices mostly. As a result of heavy subsidization of agricultural exports by developed nations, the Indian farmers have been put to serious disadvantage. The phenomenon of farmer suicides- 1256 in Bathinda and 1634 in Sangrur between 2000 and 2008 has been seen because of distress of farmers specializing in agricultural commodities and their exports.

\section{- Crop production is mainly few crops oriented}

Calling green revolution as 'wheat-rice evolution' would not be wrong because originally the five main crops were selected for purpose of use of HYV seeds that is, wheat, rice, jowar, bajra and maize but the production of rice and wheat have shown great results. Commercial crops like jute, cotton have suffered a lot. Moreover, although Bt cotton (a pest resistance HYV) was used but still the harvest could not be protected from whitefly. The pest actually attacked the revenue of farmers in Sangrur district of Punjab causing large number of suicidal deaths in 2015.

Table 4 clearly indicates the situation of more growth rate of rice and wheat production in Punjab. Wheat and Paddy covers the major portion of the gross cropped area which has increased from 47 percent in $1970-71$ to 80.64 percent in 2012-13. The area under pulses was 143 lakh hectares in 1990-91 decreased to 48 lakh hectares in 2013-14. Same deceleration applies to the production of oilseeds where area decreased from 104 lakh hectares in 1990-91 to 88 lakh hectares in 2013-14.

Table 4: Area under major agricultural crops (in 000 hectares)

\begin{tabular}{|c|c|c|c|c|c|c|}
\hline Item & $1990-91$ & $2000-01$ & $2010-11$ & $2011-12$ & $2012-13$ & $2013-14$ \\
\hline 1.Rice & 2015 & 2612 & 2826 & 2814 & 2845 & 2773 \\
2.Wheat & 3273 & 3408 & 3510 & 3527 & 3512 & 3470 \\
3.Other & & & & & & \\
cereal & 237 & 203 & 148 & 146 & 145 & 177 \\
4.Pulses & 143 & 54 & 20 & 20 & 13 & 48 \\
5.Oilseeds & 104 & 86 & 56 & 52 & 52 & 88 \\
6.Cotton & 701 & 474 & 483 & 515 & 481 & 505 \\
\hline
\end{tabular}

\section{- Procurement Policy}

The cost of cultivation is increasing due to rise in input prices. Manjeet Singh, farmer of Singho Village said "Since July, we have sprayed pesticides 10-12 times. Each spray costs about Rs. 3300 per acre.” Moreover, agricultural wages have increased due to National Rural Employment Guarantee Scheme (NREGS). The farmers have to undergo distress due to lack of procurement. Even the buffer stock operations are becoming too expensive. Large number of leakages are being examined at Public distribution system. All these factors are posing threat of globalization which is bigger challenge to food basket of India. The cost of procurement, storage and distribution needs to be reduced to increase production in Punjab. Then only Punjab agriculture could survive in foreign markets.

\section{- Investment In Agriculture}

Agricultural subsidies are fiscally unsustainable and investments by public sector in agriculture have shown the declining trend. The public investment declined from 3.4 percent of agricultural GDP in early 1980 s to 1.9 percent in 2001-03. There is a big trade off between subsidies and investments. The rise in public and private investment is crucial from enhancing growth. Private investment must be allowed but on regulated basis.

\section{Volume 5 Issue 6, June 2016 www.ijsr.net}




\section{International Journal of Science and Research (IJSR) \\ ISSN (Online): 2319-7064}

Index Copernicus Value (2013): 6.14 | Impact Factor (2015): 6.391

Table 5: Gross investment in agriculture

\begin{tabular}{|c|c|c|c|c|c|}
\hline Year & Public & Private & Total & $\begin{array}{c}\text { Public } \\
\text { (in \%) }\end{array}$ & $\begin{array}{c}\text { Private } \\
\text { (in \%) }\end{array}$ \\
\hline $1990-91$ & 4400 & 10440 & 14840 & 30 & 70 \\
$1999-00$ & 6670 & 41480 & 50150 & 17 & 83 \\
$2004-05$ & 23039 & 86967 & 110006 & 20 & 80 \\
$2008-09$ & 24452 & 114145 & 138597 & 18 & 82 \\
\hline
\end{tabular}

Source: Economic survey 2004-05, Agricultural statistics at a glance.

Table 5 containing data from Economic survey of Punjab clearly reveals that the percentage share of private sector in agricultural growth rate has accelerated more whereas declined in case of public sector. But certain regulations must be there to keep it on right track.

However, the announcement of Bharat Nirman programme in 2005 by government of India to improve agriculture and rural infrastructure is in right way but its pace has to be increased to meet global tendencies.

Economic survey (2000-03) indicating main reasons for decelerating agricultural performance states "main reason is poor export infrastructure, low level of agricultural processing, grading, quality control and packaging. Infrastructure specific to agricultural exports such as storage and fast track inland and mechanical port handling facilities, is also a limiting factor."

\section{- Trips and Patent}

The government of India has been under constant attack that the sui-generic system is against the interest of the farmers and act as impediment to development of new plant varieties. The new seed act proposed in 2004 could destroy farmer rights and destroy the bio-diversity of our seeds and crops. An American company has been granted patent right for Neem as a pesticide. Basmati rice which was universal variety in India has been patented as Kasmati and Texmati. Same danger lurks with regard to Tulsi (Basil) plant too.

Ancient use of Haldi (Turmeric) in India was sought to be patented under American law in 1995. But luckily Dr. R.A. Mashelkar, Director General of Council of Scientific and Industrial Research challenged it. The US patent office acknowledged its mistake and cancelled its patent.

\section{Suggestions to Enhance Punjab's Agricultural Competitive Spirit in Global Market}

For accelerating Punjab's agriculture actions need to be taken at first domestic level and then at international level. Then only it could survive in world market. Few suggestions have been enlisted below:

\section{A. Domestic Leve}

\section{Diversification of Crops}

The Punjabi farmer needs to shift its focus from common wheat and rice to other commercial crops like soyabean and maize, high value crops like basmati rice and durum wheat. He must move towards increasing production of livestock poultry that can reduce pressure on land for food production.
For fruits and vegetables, new processable varieties should be identified and promoted for export in the domestic markets within nation as well as at international level. Punjab's non-traditional exports needs to go in line with trend happening in rest of the world.

\section{Research and Extension}

There is a great need to shift away from individual crop oriented research focused essentially on irrigated areas towards research on crops and cropping system on plains, hills and marginal areas.

The National Commission on Farmers indicates that there is a large knowledge gap between yields in research stations and actual yields in farmer fields. The gap given by planning commission range from 5 percent to 300 percent depending upon the crop and the state.

The private participation has been encouraged in field of research and marketing as biotechnology and protection given to intellectual property guarantees them higher returns and improves efficiency in working but private sector limits its scope to rich farmers only so public sector has to address problems faced by resource deficit poor farmers.

\section{Shift to new production profile}

Developing diary industries to produce milk and milk products for urban centres of north India and global market could accelerate Punjabi farmer. The Punjab government can implement various schemes to encourage crop diversification through development of horticulture. Five cities estate have been set up in this context.

In Punjab, at present 11287 hectares area is under fish culture and there are around 8000 fish farmers. Government can provide quality fish seed of cultural varieties of fish, facilities of short term training in fish farming and to arrange visits of fish farmers to other states as this emerging occupation seems to be more lucrative. A college of fisheries has been established at GADVASU Campus in Ludhiana.

The DGCI\&C indicates that exports of fisheries sector were not regular due to changing world demand, restrictions on exports of agro products for supplementing domestic demands and uneven agro production patterns.

\section{Biotechnology}

On technology site its important to push production frontier further to increase crop yields. Hubs of processed wheat products around modernized private industries can be developed to produce dalia, atta, maida, suji, pasta in place of whole wheat. The production of soya products like soya chops, tofu, soya milk can add value to soya industries.

Alternative technologies from international research centres too can solve problem. For example, super wheat from CIMMYT, hybrid and golden rice from IRRI and dwarf pigeon pea from ICRISAT could be considered. Between cotton has provided opportunities to enhance cotton production. 


\section{International Journal of Science and Research (IJSR) \\ ISSN (Online): 2319-7064}

Index Copernicus Value (2013): 6.14 | Impact Factor (2015): 6.391

\section{International Level}

Resistance to some extent has to be built against developed countries so that level playing field is available to goods and services exported by India and other developing countries.

But excessive resistance could hamper investment opportunities in future. So the negotiations become most important because when external prices for foodgrains collapse farmers are not adequately prepared to face challenges of globalization.

Heavy import duties can be imposed to counter questionable subsidies given to agriculture products by exporting countries apart from having the option of acting under safeguard provisions to counter surge of imports.

The principle of comparative cost advantage must become the basis of trade in agriculture rather than principle of access to subsidies.

\section{Conclusion}

In conclusion, an immediate step needs to be taken by Punjab's policy both at domestic and international level to bear on future development strategies of Punjab. Bankers, entrepreneurs and farmer leaders on one table can solve the problem. An ensured enforceability of contracts in producing high value crops, freeing up of land lease markets and computerization of land records will help in easing land transactions among farmers.

The export sector of Punjab, even after enjoying innate competitive advantages in several areas such as beverages, spirits \& vinegar, residues \& waste from the food industry, organic chemicals, rubber \& articles thereof, cotton, manmade staple fibres, articles of iron or steel, tool, implement, cutlery, spoon, nuclear reactors, boilers, vehicles of tramway or rolling-stock, etc. is at an important crossroads and is awaiting for policy interventions for growth, expansion and diversification. State exporters have shown a great resentment for operational challenges they face in running their business in Punjab.

As there has been no perceptible change in policies of US and OECD countries so to share benefits of globalization in equitable manner, Punjab's competitive spirit has to be accelerated.

\section{References}

[1] Anonymous 2013. Statistical Abstract of Punjab and Economic survey of Punjab, 2012-13, Government of Punjab, Chandigarh,

[2] Economic survey of India/ Economic Survey of Punjab/ India Brand Equity Fund, 2012-13,

[3] Anonymous. 2014 Punjab Economic Survey 2013-14,

[4] Ministry of Consumer Affairs, Govt. of India 2014,

[5] Anonymous. 2014 Ministry of Agriculture, Government of India 2014,

[6] Gulati, A. 2002, Challenges to Punjab Agriculture in a globalizing world, IFPRI and ICRIER, New Delhi'
[7] Johl, S.S. and Ray, S.K. 2002. Future of Agriculture in Punjab (ed.), Centre for Research in Rural and Industrial Development, Chandigarh,

[8] Sidhu, H.S. 200. Crisis in agrarian economy in Punjab : Some urgent steps. Economic and Political weekly. 37(30) : 3132-3138,

[9] Singh, Sukhpal (2000), Dynamics of Rural Poverty, Anmol Publications Pvt. Ltd., New Delhi,

[10] Punjab Human Development Report 2008, available at $<$ http://dataundp.org.in/shdr/Punjab/06gender.pdf $>$ p. 114.

[11] Shiva, V. (1991). The violence of Green Revolution: third world agriculture, ecology and politics. Zed Books.

[12]Bhalla, G. S., \& Chadha, G. K. (1982). Green Revolution and the Small Peasant: A Study of Income Distribution in Punjab Agriculture: I. Economic and Political Weekly, 826-833.

[13] www.punjabgovt.nic.in 